\title{
Supervision Strategy in Improving Teacher Quality at Universitas Islam As-Syafi'iyah
}

\author{
Sri Lestari ${ }^{1}$, Ma'ruf Akbar2, Budi Santoso ${ }^{3}$ \\ 1,2,3 Universitas Negeri Jakarta, Indonesia
}

Corresponding Author: Sri Lestari 0 SriLestari_764715801@mhs.unj.ac.id*

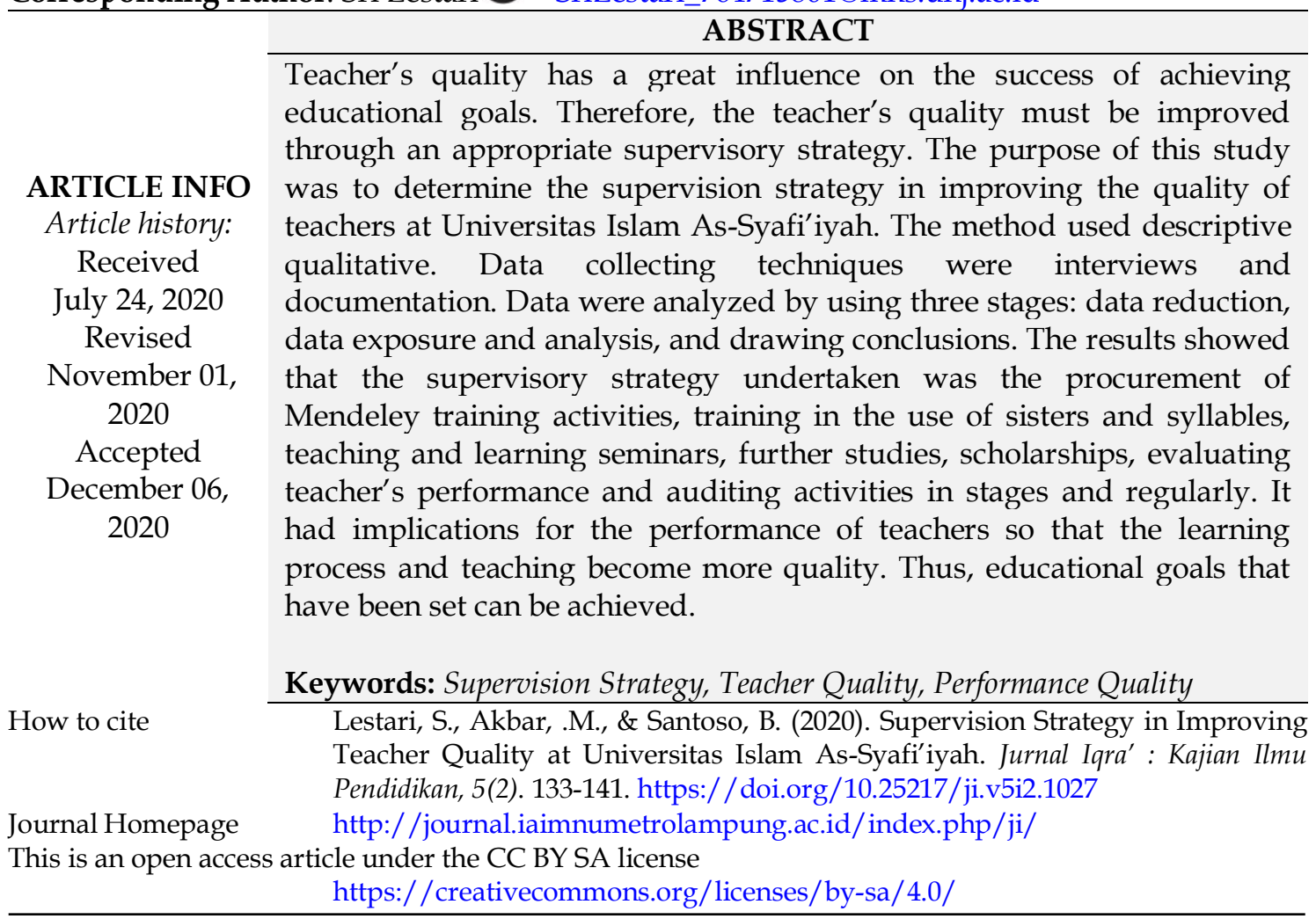

\section{INTRODUCTION}

The importance of human assets causes the prominent of measuring the value of intangible assets. Measurement means to assess how well the use and effectiveness of human capital management is. In making policies regarding the development of human capital, human resources at Universitas Islam As-Syafi'iyah received less attention. Sometimes, it did not involve lower level teachers in decision making, policies should pay attention to the needs and input of subordinates so that decisions are not only taken unilaterally by leader. The importance of the role of human resources in company activities, the company should need to manage human resources as best as possible because the key to a company's success is not only on technological excellence and the availability of funds, but also on human factors. Thus, human capital is not positioning humans as capital like machines so as if humans are the same as machines. But human capital can actually help decision makers focus on human development in order to improve organizational quality. Therefore, companies must be able to improve the quality of human resources in facing challenges, and also to achieve the company's vision and mission. Humans and other social beings share the altruistic nature of reciprocity, which enables them to engage in social endeavors that 
provide the most abundant benefits for more than one party (Hermann \& Hermann, 2017). Human resources must be improved according to their competence (Sherm 'on, 2004).

From this view, University should have carried out a process of increasing the resources of teachers as educators who are able to carry out their duties properly. However, some processes of improving the teacher's quality through the supervisory strategy are less precise and still face many obstacles. The results of observations in the preliminary research found problems, namely 1) irregular design of activities, 2) types of activities that were not well targeted and purposeful, 3) mapping needs of the implementation of Tri Dharma College were not consistent, 4) decision making about activities to improve the quality of teachers unilateral from the leadership and it is not in accordance with the needs of the field, and 5) assessment of the performance load of teachers who are not well targeted.

These problems can be seen that the supervision system is implemented by the University has not been able to improve the quality of teachers. Some research have been done relating with the quality of teachers and research related to human resource management (Steffensen, Ellen, Wang, \& Ferris, 2019). Yasir has improved the quality of teachers through the activities of growing the values of sincerity, trust given by the government and society, maintaining and improving a quality work ethic (Yasir, 2018). In addition, teachers' competency improvement activities can be carried out through coaching activities, scientific activities like as seminars, symposiums, and scientific publications through journals or national and international proceedings to support the tri dharma activities of higher education institutions in educational and teaching activities (Dewi, 2018). Management of higher institutions or university is to develop teachers' resources in accordance with government policies in order to achieve the quality of teachers. It is appropriate with the Education Laws. In addition, university should also collaborate with other parties to carry out the tri dharma of higher education (Nurmilah, 2018). Thus, the quality of higher education services can be influenced by the quality of teachers. Therefore, universities should be able to influence the feasibility of teaching, the percentage of permanent teachers, the percentage of functional teachers' positions, the percentage of teachers' pensions, the percentage of teachers seniority, the percentage of educational staff pensions, and the percentage of educational staff diplomas (Hermawan, 2011). Teachers development can also be done through improving professional management (Sulastri, 2013). Teachers' quality also have a positive impact on the quality of education services (Chairunnisa, 2015).

Previous research is oriented to the overall management of higher institutions and managing quality of education services. Therefore, this research was conducted more oriented to the supervision strategy of the quality of lecturers. The quality of teachers refers to the performance so that the supervision can be related to the quality of teaching and learning. However, this research is different with the previous study. It was conducted on the grounds that each University has a different supervisory strategy, an oversight strategy adapted to the problems and characteristics of the University, and different management models.

This research is important to do because several reasons, namely 1) understanding of empirical-oriented supervision, 2) evaluation of teacher performance according to university characteristics, 3) universities have different characteristics in conducting supervision, 4) management of performance management at the Universitas Islam As-Syafi'iyah needs a concept renewal, and 5) the Universitas Islam As-Syafi'iyah Pondok Gede builds a concept of supervision that leads to 
professionalism. Thus, this research is expected to provide benefits to the development of teacher performance supervision that can be carried out regularly and in accordance with the characteristics of the university's needs. The purpose of the research is to obtain in-depth information about the strategies implemented by the Universitas Islam As-Syafi'iyah in improving teacher quality. This is a top priority in the study, because the teacher's supervision or assessment process should be able to provide improvements to the achievement of learning objectives. From the problems that have been explained, it can be seen that the problem in this research is how the supervision strategy is used to improve the quality of teachers at the University.

\section{METHOD}

This research used a qualitative approach with qualitative descriptive methods. Ary, Jacobs, Sorensen, \& Razavieh (2010) stated that qualitative research refers to the study of social phenomena or facts that occur in the field. Qualitative research involves important efforts, such as asking questions and procedures, collecting specific data from participants, analyzing data inductively starting from specific themes to general themes and interpreting the meaning of data (Creswell, 2012). This research report has a flexible structure or framework. Anyone involved in research translates the complexity of an issue. Therefore, this study examines facts relating to the use of supervisory strategies for the quality of teachers at the Islamic University of AsSyafi'iyah Jakarta. To obtain the use of the monitoring strategy, the data collection in this study used;

1. Qualitative observations, researchers refer directly to the field to observe the behavior and activities of employees at the study site. Researchers record both structured and semistructured, for example asking questions that really want to be known by researchers.

2. Qualitative interviews, researchers can conduct interviews with resource persons using unstructured and open-ended questions that are designed to bring up the views and opinions of the participants. There are nine informants that will be interviewed, i.e Rector (MA), Vice of Rector (HS), Director of Human Resources (AD), Dean (DM), Deputy Dean (MD, MN, and HD), Head of Study Program (SF), and Lecturer $(\mathrm{HH})$. The interview aims to get the supervision activity.

3. The researcher collects qualitative documents, which can be in the form of reports and other supporting documents.

4. Researchers collect data in the form of photos, videos. In addition, secondary data is the form of documentation obtained during observations in university.

This research was conducted in the campus environment of the Islamic University of As-Asyafi'iyah Pondok Gede in Jakarta which is located in 2 adjacent locations divided into 2 campuses namely Campus 1 (Faculty of Economics and Business) and Campus 2 (Faculty of Law, Faculty of Islamic Religion, Faculty of Science and Technology, Faculty of Teacher Training and Education, Faculty of Health Sciences).

The validity of the data in qualitative research like as interview and observation includes the data credibility test (internal validity), transferability test (external validity), dependability test (reliability), confirmability test (objectivity).

\section{RESULT AND DISCUSSION}

Islamic University of As- Asyafi'iyah has made various efforts to improve the quality of teachers in accordance with operational standards set by the University. The results of the analysis of the data obtained found several data findings in improving 
the quality of teachers, among others; 1) the lecturer recruitment system that has not been set high standards, 2) the lecturer recruitment planning is not adjusted to the needs planning map because it is done incidentally, 3) the number of lecturers who are not yet doctoral is still large, 4) the lack of encouragement from universities for lecturers in managing academic functional positions, 5) shortages of lecturers are often not taken seriously because the recruitment of lecturers is sometimes carried out waiting for lecturers to leave or retire, 6) activities to increase the ability to teach and learn a little, 7) untidy teacher data management, and 8) evaluation of programs or teaching activities in the semester is still not organized regularly.

While some constraints have been resolved through a number of ways including 1) involving teachers is to make decisions about the activities needed, 2) leaders often have discussions with teachers on the development needs. This discussion activity became one of the social approaches in building cooperation between the leadership and the entire academic community. This is quite effective in knowing the level of cooperation undertaken. Social strategies are used to describe the quality of individual responses to institutional pressure. 3) Determination of a larger allocated budget in accordance with the needs of the activities that have been determined, 4) designing a continuous and systematic evaluation system, and 5) a schedule of activities tailored to the teaching schedule and scientific needs. The University also conducts control and outreach to programs that have been routinely designed so that the University knows the obstacles and progress of its activities. Socialization activities are carried out on faculties systematically

Therefore, from the findings that have been identified, this study provides input into activities in the supervision of improving the quality of teachers, as listed in the following table.

Table 1. Activity in Improving Teacher' Quality as Supervision Strategy Program

\begin{tabular}{|c|c|c|c|}
\hline No & Code & Supervision Activity & Purposes \\
\hline 1 & PC1 & $\begin{array}{l}\text { Human Resource System } \\
\text { training in Sister and Sinta } \\
\text { applications }\end{array}$ & $\begin{array}{l}\text { Improving } \\
\text { comprehending of the use of } \\
\text { Sister and Sinta applications } \\
\text { relating to teacher data }\end{array}$ \\
\hline 2 & PC2 & Mendeley training & Improving the ability in citation \\
\hline 3 & PC3 & $\begin{array}{l}\text { Seminar on teaching and } \\
\text { learning }\end{array}$ & $\begin{array}{l}\text { Developing the knowledge and } \\
\text { skills of teachers in teaching and } \\
\text { learning. }\end{array}$ \\
\hline 4 & PC4 & $\begin{array}{l}\text { Continuing education to a } \\
\text { higher level, like as S3 }\end{array}$ & $\begin{array}{l}\text { Improving the academic quality } \\
\text { of teacher }\end{array}$ \\
\hline 5 & PC5 & Giving Scholarships & $\begin{array}{l}\text { Easing the burden on teachers in } \\
\text { continuing their education to a } \\
\text { higher level }\end{array}$ \\
\hline 6 & PC6 & Evaluate & Finding the progress of teachers' \\
\hline
\end{tabular}




\begin{tabular}{|l|l|l|l|}
\hline & & performance every semester & quality learning. \\
\hline 7 & PC7 & Audit program & $\begin{array}{l}\text { The evaluation of activities in } \\
\text { education process. }\end{array}$ \\
\hline
\end{tabular}

Table 1 provides conclusions about matters related to problem-solving activities found in improving teacher quality. The monitoring strategy carried out has a variety of different activities. Various activities carried out have been adjusted to the needs so that the educational goals to be achieved by the university can be achieved in accordance with the needs of industry and the business world. Because teachers are media or facilitators who have an important role in the education system. Factors driving the achievement of teachers' development include: seriousness and responsibility, teachers' awareness of the need for self-improvement such as training and seminar activities, teachers' quality control systems and the availability of sufficient funds and Operational Standards. However, the implementation of the activities showed the seriousness of the person in charge of carrying out these tasks, consistent in the implementation of the program, the existence of a vision and mission that was handed down to each Faculty.

The results of the data analysis also showed that the inhibiting factors faced in developing the potential of teachers included: 1) lack of interest in teachers to develop due to lack of teachers involvement in making program decisions, 2) lack of cooperation from leaders with other academic community members, 3) budget the cost for developing teachers is still small, 4) the use of the system that has not been effective, and 5) there are assumptions of some teachers who do not want to attend seminars and training held at the Islamic University of As-Syafi'iyah Jakarta because of the target of unnecessary activities. In addition, the constraints of training or seminar hours are the same as the teaching hours.

Education and human resource development are two factors that are interrelated with one another. In other words, high quality education will result in high quality human resources, such as the presence of teachers who have a major influence on the delivery of education in educational institutions. To produce qualified teachers, it is necessary to measure (assess) the teachers so that the goals of the organization's vision and mission are achieved. In terms of teacher assessments that have been carried out at As-Syai'iyah Islamic University from the finding data, the aim is to determine the readiness of teachers in teaching, the material presented is easy to understand by students, the ability of the teacher is to deliver material to students, the accuracy of time discipline, mastery of material and knowledge of the subjects being taught, receiving criticism and input from students. This component is an achievement to be realized in order to implement a good educational process. This can be seen from the supervisory activities that have been described in table 1. Having competent and qualified teachers is expected to be an added value in the community to produce graduates. So, in organizational development there must be cooperation between teachers and students or teachers with all parties in the university. Teachers provide support to students in terms of teachers, training and seminars held on campus which can be useful for adding broad insights and knowledge. This form of support is also provided by the university to the teachers.

The process of monitoring the quality of teachers must be carried out regularly (Zoulikha, 2014). The supervision process is one way to find out the professional identity of teachers in the university environment (S.Ibrahim, 2013). There are five 
features for the professional community that can help someone's work, such as collaboration norms, trust, practical activities, access to information and expectations to be achieved together in supervision activities (H.Levine, 2011). Besides, the university can be used the peer coaching in improving the teacher's quality. Peer coaching affects teacher self-confidence, autonomy and learning. Thus, interaction has the important role between teacher and students in creating the learning process (J.Long, Es, \& W.Black, 2013).

Some of solutions become very appropriate to the needs of developing teacher quality, as has been proven by Razak, Syah, \& Aziz (2016) that leadership has a very large role in increasing the exclusion of activities carried out in a certain period of time. Teachers also as professionals have an awareness of self-quality improvement. Whereas (Razak et al., 2016) improved the quality of teaching staff through quality learning and reformed the education management system with well-managed institutional management. Professional development of teachers can have an impact on improving the quality of teaching and interaction between teachers and students. As said by Razak et al. (2016) shows professional development in services on the quality of teacher-child interaction in education and early care is very good.

Teachers also have a high level of awareness to improve their quality in participating in various activities carried out by the University. Training activities and seminars become one of the most effective media to improve self competence. As it has been explained by Wattimena (2010) that training, internships, seminars and upgrading have succeeded in improving the quality of teachers. Knowledge-based workshops, to some extent, have a positive effect on teacher confidence and self-efficacy, this effect is not sustainable over time (Chen, 2020). Continuous professional development has a great influence on reflective improvement, and collaborative activities are related to increasing self-efficacy. However, participation in reflective and collaborative activities only benefits experienced teachers (Li, Liu, Chen, \& Yao, 2019; Lauermann \& König, 2016).

The same thing has been done by Sulastri (2013) to improve the quality of teachers can be done by improving performance at the Tarbiyah Faculty of the University of Muhammadiyah Aceh through fostering qualifications and increasing teachers' competence through further study assignments, upgrading, workshops, and seminars. In addition, audit activities are often carried out regularly with the aim of knowing the success of the program. Audit activities are carried out in accordance with the system that has been used at Islamic University of As-Syafi'iyah Jakarta, even though the system used has not met the set operational standards. However, the University has done a very good planning according to the level of ability both from providing activity funds for teacher development programs.

Thus, teachers have a very important role. From the supervisory strategy that has been carried out at Islamic University of As-Syafi'iyah Jakarta through training activities, seminars, regular evaluation of the teachers performance load and further study has a great impact on quality teaching and learning. Universities can also carry out supervision activities by building the peer assessment concept (Halim et al., 2010; Alsaleh et al., 2017). One of the things teachers can do in developing teaching is to develop teaching materials (Pardo \& Téllez, 2009). Teachers always make creativity in accordance with the global development of science that must be possessed by students. Teachers have also been very easy in utilizing the technology applied in classroom learning. This means that educators must be able to face the changing world quickly. Teacher education reforms throughout the world have been oriented towards making 
teacher preparation more functional for the development of the competencies they need in practice (Pantić \& Wubbels, 2010).

The results of this study provide quite good implications for the results of improving the quality of teachers at Universitas Islam As-Syafi'iyah. This can be seen from the implementation of the findings for teachers who are enthusiastic about selfdevelopment. The university also improves the management of the teaching career. In academic practice, teaching professional development is very important information for instructors and universities are obliged to inform the development of career policies (van Dijk, van Tartwijk, van der Schaaf, \& Kluijtmans, 2020). Teaching quality results can be a beneficial outcome for the instructor as a whole as evidence of their selfquality assessment (Graham, White, Cologon, \& Pianta, 2020) and ways of promoting teachers to teach (Dong, Wang, Han, \& Zhang, 2018).

Therefore, the results of this study recommend that universities develop procedures and management systems for teaching staff with an orderly system and following current global needs so that the implementation of the education process can provide competitive quality. In addition, some of the results of research analysis can be used as a way of solving problems in building skills, knowledge and motivating teaching staff or all those in the university environment.

\section{CONCLUSION}

The results of the data analysis show that the Islamic Universitas Islam AsSyafi' iyah has improved the quality of teachers with a variety of program activities that meet the needs of both the teachers' needs themselves in carrying out their tasks, as well as from scientific and global developments. Some training activities and seminars provide knowledge that can be used by teachers to improve their competence. Likewise, with further studies at higher levels can be used to improve teaching competence, social or professionalism as an educator. This has an impact on the development of teaching and learning models. Because basically the learning process either by teachers or students is a lifelong learning process. It means that the teachers has carried out self-development for a lifetime (Finsterwald, Wagner, Schober, Lüftenegger, \& Spiel, 2013). The supervision conditions that have been carried out also provide significant changes to the social relations of the entire academic community in the campus environment.

\section{ACKNOWLEDGEMENT}

Thank you to all people that have helped me to finish this research at Universitas Islam As-Syafi'iyah.

\section{AUTHOR CONTRIBUTION STATEMENT}

Sri Lestari (SL) was the main author in this paper. MA and BS were the second and the third author that help the main author to finish this research. They have guided the main author.

\section{REFERENCES}

Alsaleh, A., Alabdulhadi, M., \& Alrwaished, N. (2017). Impact of peer coaching strategy on pre-service teachers' professional development growth in Kuwait. International Journal of Educational Research, 86, 36-49. https://doi.org/10.1016/j.ijer.2017.07.011

Ary, D., Jacobs, L. C., Sorensen, C., \& Razavieh, A. (2010). Introduction to Research in 
Education (8 Edition). CA: Cengage Learning. Google Scholar

Chairunnisa, C. (2015). Hubungan tata kelola universitas dan profesionalitas dosen, dengan mutu layanan pendidikan. Faktor Jurnal Ilmiah Kependidikan, 2(3). http:// dx.doi.org/10.30998/.v2i3.479

Chen, G. (2020). A visual learning analytics (VLA) approach to video-based teacher professional development: Impact on teachers' beliefs, self-efficacy, and classroom talk practice. Computers and Education, 144, 103670. https://doi.org/10.1016/j.compedu.2019.103670

Creswell, J. W. (2012). Educational Research: Planning, Conducting, and Evaluating Quantitative and Qualitative Research. London \& New York: Pearson Education. Google Scholar

Dewi, C. (2018). Manajemen pengembangan kompetensi dosen. jmsp: Jurnal Manajemen Dan Supervisi Pendidikan, 3(1). Google Scholar

Dong, Q. W., Wang, S. M., Han, F. J., \& Zhang, R. D. (2018). Innovative Research and Practice of Teachers' Teaching Quality Evaluation under the Guidance of "Innovation and Entrepreneurship." In Procedia Computer Science (Vol. 154, pp. 770-776). Elsevier B.V. https:// doi.org/10.1016/j.procs.2019.06.123

Finsterwald, M., Wagner, P., Schober, B., Lüftenegger, M., \& Spiel, C. (2013). Fostering lifelong learning - Evaluation of a teacher education program for professional teachers. Teaching and Teacher Education, 29, 144-155. https:// doi.org/10.1016/J.TATE.2012.08.009

Graham, L. J., White, S. L. J., Cologon, K., \& Pianta, R. C. (2020). Do teachers' years of experience make a difference in the quality of teaching? Teaching and Teacher Education, 96, 103190. https:/ / doi.org/10.1016/j.tate.2020.103190

H.Levine, T. (2011). Features and strategies of supervisor professional community as a means of improving the supervision of preservice teachers. Teaching and Teacher Education, (7), 930-941. Google Scholar

Halim, L., Buang, N. A., \& Meerah, T. S. (2010). Action research as instructional supervision: Impact on the professional development of university based supervisors and science student teachers. In Procedia - Social and Behavioral Sciences (Vol. 2, pp. 2868-2871). Elsevier. https:/ / doi.org/10.1016/j.sbspro.2010.03.430

Hermann, H. R., \& Hermann, H. R. (2017). Human Nature. Dominance and Aggression in Humans and Other Animals, 115-138. https://doi.org/10.1016/B978-0-12-8053720.00008-0

Hermawan, I. K. D. (2011). Analisis Sumber Daya Manusia Pendidikan Tinggi. Jurnal Pendidikan Dan Kebudayaan, 17(4). Google Scholar

J.Long, J., Es, E. A. va., \& W.Black, R. (2013). Supervisor-student teacher interactions: The role of conversational frames in developing a vision of ambitious teaching. Linguistics and Education, 24(2), 179-196. Google Scholar

Lauermann, F., \& König, J. (2016). Teachers' professional competence and wellbeing: Understanding the links between general pedagogical knowledge, self-efficacy and burnout. Learning and Instruction, 45, 9-19. https:/ / doi.org/10.1016/J.LEARNINSTRUC.2016.06.006

Li, R., Liu, H., Chen, Y., \& Yao, M. (2019). Teacher engagement and self-efficacy: The mediating role of continuing professional development and moderating role of teaching experience. Current Psychology. https://doi.org/10.1007/s12144-01900575-5

Nurmilah, R. (2018). Peningkatan mutu dosen perguruan tinggi swasta di kabupaten jombang (Studi Multi Kasus di Univerditas Pesantren Darul Ulum dan 
Universitas Hasyim Asy'ari Jombang). In Seminar Nasional Multidisiplin (pp. 6679). Google Scholar

Pantić, N., \& Wubbels, T. (2010). Teacher competencies as a basis for teacher education - Views of Serbian teachers and teacher educators. Teaching and Teacher Education, 26(3), 694-703. https:// doi.org/10.1016/J.TATE.2009.10.005

Pardo, A. N., \& Téllez, M. F. T. (2009). ELT Materials: The Key to Fostering Effective Teaching and Learning Settings. Profile Issues in Teachers'Professional Development (Vol. 11). La Universidad Nacional de Colombia. Google Scholar

Razak, Y., Syah, D., \& Aziz, A. (2016). Kepemimpinan, kinerja dosen dalam peningkatan mutu pendidikan perguruan tinggi. tanzim Jurnal Penelitian Manajemen Pendidikan, 1(2). Google Scholar

S.Ibrahim, A. (2013). Approaches to supervision of student teachers in one UAE teacher education program. Teaching and Teacher Education, 34, 38-45. Google Scholar

Steffensen, D. S., Ellen, B. P., Wang, G., \& Ferris, G. R. (2019). Putting the "Management" Back in Human Resource Management: A Review and Agenda for Future Research. Journal of Management, 45(6), 2387-2418. https://doi.org/10.1177/0149206318816179

Sulastri, E. (2013). Strategi peningkatan kinerja dosen fakultas tarbiyah universitas muhammadiyah aceh. Jurnal Mentari, 16(1). Google Scholar

van Dijk, E. E., van Tartwijk, J., van der Schaaf, M. F., \& Kluijtmans, M. (2020). What makes an expert university teacher? A systematic review and synthesis of frameworks for teacher expertise in higher education. Educational Research Review, 31, 100365. https:// doi.org/10.1016/j.edurev.2020.100365

Wattimena, F. (2010). Implementasi Strategi Pengembangan Sumber Daya Manusia dan Dukungan Organisasi Terhadap Peningkatan Kualitas Dosen Fakultas Ekonomi Universitas Pattimura Ambon. Jurnal manajemen dan kewirausahaan, 12(2). https://doi.org/10.9744/jmk.12.2.pp.\%20195-208

Yasir, S. N. H. (2018). Manajemen peningkatan kualitas doseN (Studi Kasus pada Fakultas Tarbiyah UIN Malang). JRTIE: Journal of Research and Thought of Islamic Education, 1(1). Google Scholar

Zoulikha, T.-M. (2014). Supervision of Primary School Teachers an Analytical Field Study. Procedia - Social and Behavioral Sciences, 112, 17-23. https://doi.org/10.1016/J.SBSPRO.2014.01.1135

\section{Copyright Holder :}

(c) Lestari, S., Akbar, .M., \& Santoso, B. (2020).

First Publication Right :

(c) Jurnal Iqra' : Kajian Ilmu Pendidikan

This article is under:

() (1) (2) 